\title{
Learning Innovation Online Course Based on Blended Learning for Interactive Learning in The Era of Education 4.0
}

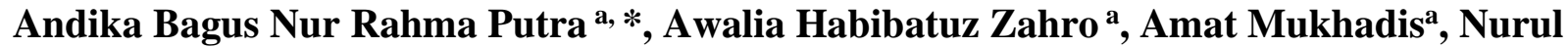 \\ Ulfatin $^{b}$, Muhammad Ashar
}

${ }^{a}$ Faculty of Engineering, Universitas Negeri Malang.

Jalan Semarang No.5, Malang, 65145, Indonesia

${ }^{b}$ Faculty of Education, Universitas Negeri Malang

*E-mail: andika.bagus.ft@um.ac.id

\begin{abstract}
The objectives of this study: (1) developing online learning innovations based on blended learning for interactive learning media era education 4.0; and (2) testing the attractiveness of the product being developed. The development of Quipper School learning tools follows the 4-D model (namely defining, designing, developing, and disseminating). The results of this study include: (1) quipper school has several advantages to help the learning process, including students being able to learn independently, learning that is fun and interesting through features, displaying material and varied videos, students can practice questions, and teachers can monitor the progress of student learning; (2) Quipper School media which is proven to improve student learning outcomes.
\end{abstract}

\section{Introduction}

The world is entering the era of the industrial revolution 4.0. The fourth world industrial revolution in which technology has become a major force in human life (Chai, Koh, \& Teo, 2019; Henritius, Löfström, \& Hannula, 2019; Khlaisang \& Songkram, 2019; Kim, Raza, \& Seidman, 2019). Everything has become limitless due to the development of the internet and digital technology. This era has influenced many aspects of life both in the economic, political, cultural, artistic, and even to the world of education. The digital revolution and the era of technological disruption are other terms of industry 4.0. Called the digital revolution because of the proliferation 
of computers and the automation of record-keeping in all fields (Broton, 2019; Hu, Hu, Liu, Chen, \& Qin, 2018; Skorton, 2019).

Industry 4.0 to be the era of education 4.0 because automation and connectivity in the field of education will make the movement of the industrial world and work competition become nonlinear (Bedir, 2019; Kim et al., 2019; Schietroma, 2019). One of the unique characteristics of Industry 4.0 is the application of artificial intelligence. One form of implementation is the use of robots to replace human labor so that they are cheaper, more effective and efficient (Akhyar, Sajidan, Akhyar, \& Suryani, 2019; Kembara, Rozak, \& Hadian, 2019; Melo, 2018; Zulkarnaen, Setiawan, Rusdiana, \& Muslim, 2019).

Relationship of the world of education with the industrial revolution 4.0. affect the world of education. It makes the world of education is required to have to follow the development of technology that is developing rapidly. In addition, it is necessary to utilize information and communication technology as more and all-advanced facilities to expedite the learning process. The main hope of this is that the use of information and communication technology learning mindsets can shift from being teacher-centered to student-centered. Technology in the world of education is usually called e-learning (Pandit, Joshi, Gupta, \& Sahay, 2017; Saggaf, Salam, Wirawan, \& Hasanuddin, 2018; Strekalova, Karimipour, James, \& Treise, 2018).

The main contribution of e-learning facilities is to facilitate the learning process and learning. The use of e-learning in learning according to the latest research has a positive impact on the process and learning outcomes, in general, there are two factors that influence learning outcomes, namely internal factors and external factors (Daniels, Sarte, \& Cruz, 2019; Elsawy \& Ahmed, 2019; Srinivasan, Al-omairi, Muppidathi, \& Al-balushi, 2019). Interest in learning included in one of the internal factors has a close relationship with learning outcomes. This means that in addition to having a positive impact on learning outcomes, the use of technology in learning can have a positive impact on learning interest. In addition, learning that is only centered on the teacher and books will make students bored with learning in class. Therefore, learning innovation is needed one of them with technology-based learning so that the appearance and learning style is more interesting to make students avoid boredom and boredom when participating in learning (Chan, 2019; Kong, 2019; Ranieri, Raffaghelli, \& Pezzati, 2018).

At this time many e-learning learning media have been developed. Applications supporting elearning can be in the form of Edmodo, google classroom, quipper school, and so on. One of the e-learning trends is quipper school (Elsawy \& Ahmed, 2019; Han \& Ellis, 2019; M Mustari, Hoya, Akmansyah, Diani, \& Asyhari, 2019). Quipper schools can be accessed using a smartphone, PC/computer, laptop or tablet. Through Quipper School, teachers can monitor student learning 
activities, view data analysis/graphs of student development, see which topics analysis has been or has not been mastered by students, send private messages or respond to student questions, make announcements for students, and print (print) value results. Until now, the use of the word elearning is often used by all educational activities that use internet media. Students do not need to be in the classroom to listen to every remark from a teacher directly with the help of e-learning. E-learning can also shorten the target schedule of learning time and save costs incurred by a study program or education program (Montgomery, Mousavi, Carbonaro, Hayward, \& Dunn, 2019; Simarmata, Djohar, Purba, \& Juanda, 2018; Yeop, Yaakob, Wong, Don, \& Zain, 2019)

\section{Method}

In this study, the development of Quipper School learning tools was carried out. The development of Quipper School learning tools follows the 4-D model (defining, designing, developing, and disseminating).

\section{A. Defining}

The defining phase aims to define the terms of learning done in blended learning. At this stage, an analysis of the objectives of the boundaries of the learning material will be developed. Analysis of objectives is adjusted to students, the competencies achieved, and the implementation of learning later. Through this defining stage, the learning process becomes transparent, directed and in accordance with what is to be achieved.

\section{B. Design}

The results obtained at the design stage are blended learning based devices in the form of Quipper School applications, Learning Implementation Plans (RPP), and learning achievement tests. The Quipper School application contains learning material, achievement tests, and features to support the learning process on the competence of applying differential care methods. The Learning Implementation Plan (RPP) is prepared according to the learning objectives to be achieved as a blended learning Quipper School learning scenario.

The test is arranged with the steps: (1) identify the basic competencies of applying differential maintenance methods; (2) compiling indicators of achieving learning objectives; (3) compilation of questions grids; (4) analyzing the suitability of the problem line with the indicators; (5) preparation of test items; (6) analyzing the suitability of the questions lattice with the test items; (7) determining valuation techniques; (8) expert test instrument test; 9) small group test instrument testing; (10) expert test analysis and small group test instrument testing; (11) revision of the test items; and (12) finalization of test items. 


\section{Development}

The development phase includes validation of learning tools by experts (media experts, materials, and test instruments) followed by revisions, simulations of learning activities according to the learning plan, and small group trials. A small group trial was conducted by students of the class in SMK PGRI 3 Malang. The class was chosen because it was guided by the same TKRO teacher as the class that would be used for research and recommendations from the TKRO teacher that the class had students who had equal learning abilities compared to other classes. The trial results are then used to improve the Quipper School learning tool based on blended learning

\section{Dissemination}

Blended learning Quipper School tools that have been developed later through the dissemination phase. The dissemination phase is carried out in subsequent studies through quasiexperimental research to test differences in learning outcomes between students who are treated using Blipper learning-based learning Quipper School with learning using slide presentations on the competence of applying differential care methods.

\section{Results and Discussion}

\section{A. Learning Instrument Test Results}

The Quipper School application developed has several superior features. The features of Quipper School include a homepage, differential material, video differential, practice exercises, messages, pre-test questions, and post-test questions. These features are described in Figure 1.
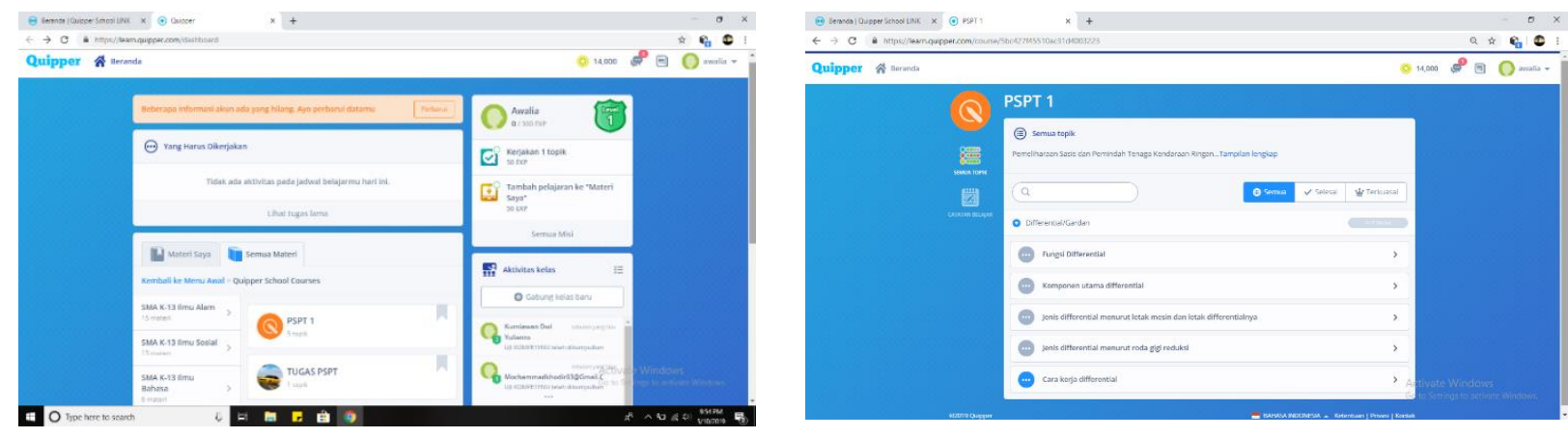

Figure 1. Quipper School Student Home

Figure 1 is the display of the student account homepage on the Quipper School application. The top right corner tool contains the student account name, notifications, messages, and points students get after completing the subject matter. On the main screen display contains the assignments that students must do, the subject matter is in accordance with the subjects students are taking, and class activities. Students can adjust the appearance of wallpaper using points that 
have been obtained so that the account owned is more interesting and can be created according to the wishes of students

The competence to apply differential maintenance methods is in the subject of chassis maintenance and power transfer (PSPT). Students can learn about differential material by clicking PSPT 1 on "My material" and a differential submitter display will appear on Quipper School is shown in Figure 2.

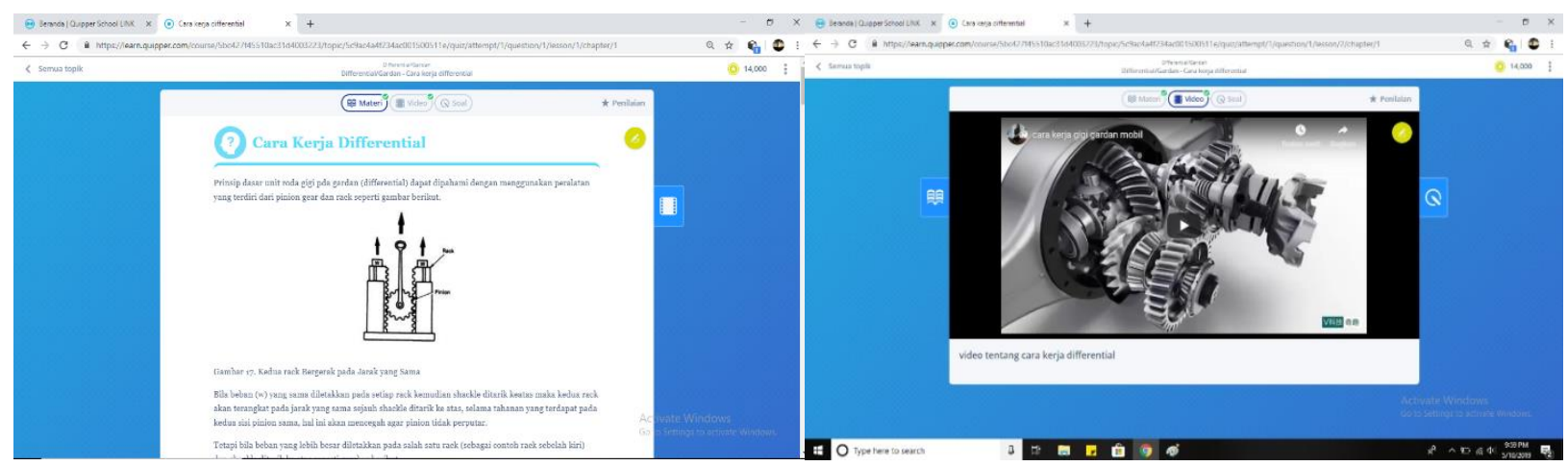

Figure 2. Video Differential Quipper School

In each section of differential material, there is a video like in picture 2. The video shown can help students understand the subject matter. The video is connected to the youtube link that you have specified. In the question exercise feature, students can practice their knowledge after studying the material and videos that have been provided. Students can practice by working on as many problems as possible. The teacher can monitor student activities through the achievement of the material that has been learned and how many questions can be solved. This is shown in Figure 3.
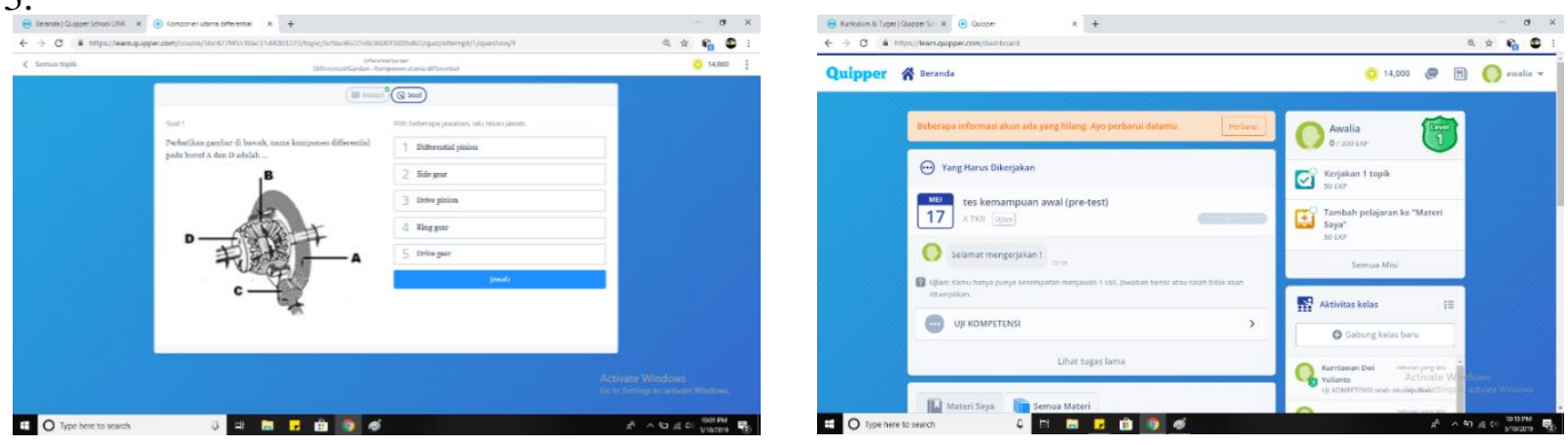

Figure 3. Exercise of Differential Quipper School Questions

The agenda feature contains practice exercises to improve student skills and learning achievement tests in the form of pre-test and post-test. The pre-test display can be seen in Figure 3. The pre-test questions are displayed and done at the beginning of learning to measure students' initial abilities. Post-test questions are displayed and done after students have done the learning using Quipper School and completing the given assignment. Post-test questions are used to measure student learning outcomes. The second characteristic of the questions developed is in the 
form of multiple-choice questions on competency applying differential care methods and consists of 30 items arranged based on five competency indicators.

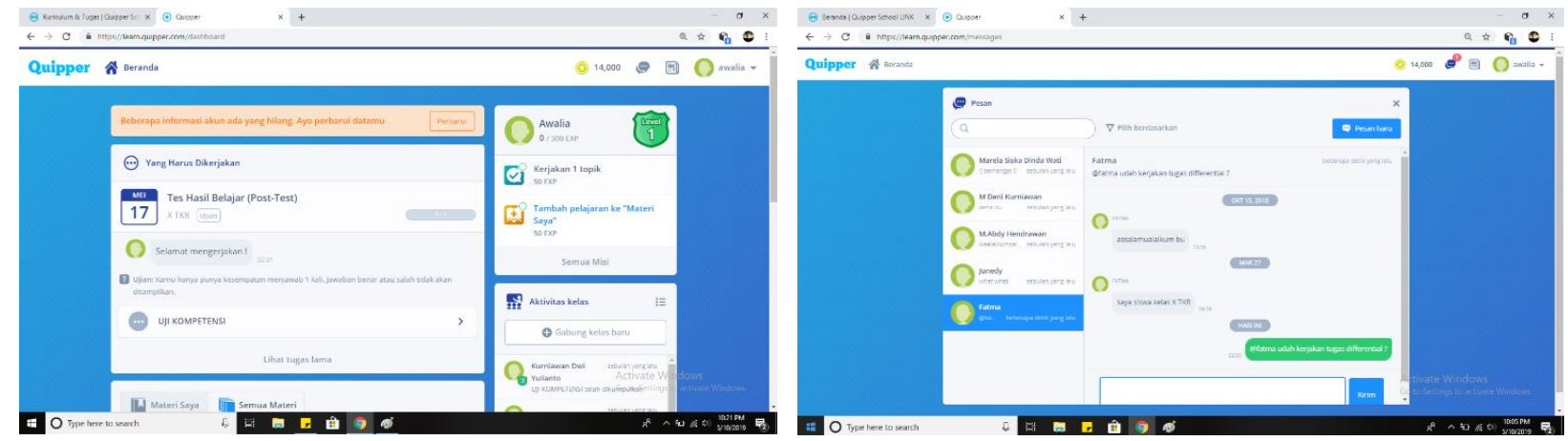

Figure 4. Post-Test Differential Quipper School

The message feature in the Quipper School application can be seen in Figure 4. The message feature contains communication between the teacher and students or between students to facilitate students when having difficulties in learning about the material presented. This messaging feature can be used as a forum for discussion of material about differentials. Students can express their difficulties in learning directly to the teacher without waiting for class meetings and train students to express their opinions to other students and teachers. The results of the media and material expert assessment of the RPP and the Quipper School application obtained are then calculated using the percentage validity formula. The percentage of validity obtained is $86 \%$. This result is matched with the validity criteria table. A percentage value of $80-100 \%$ indicates that the instrument is very valid and can be used for further research stages. In addition to assessing aspects of the RPP instrument and the Quipper School application, the validator expert also gave suggestions in the form of adding practice questions and adding video supporting learning materials. The results of the expert test instrument assessment of the pre-test and post-test questions obtained are then calculated using the percentage validity formula. The percentage of validity obtained is $88.89 \%$. The percentage value of validity is on a scale of $80-100 \%$, this shows that the instrument is very valid and can be used for further research stages. In addition to assessing aspects of the instrument, the validator also submitted suggestions for improvement in the form of pictures on the questions in clear and simpler sentence sentences.

Media Quipper School based on blended learning is provided to help the formation of knowledge carried out by students (Burac, Fernandez, Cruz, \& Cruz, 2019; Elsawy \& Ahmed, 2019; Mcguinness \& Fulton, 2019; Srinivasan et al., 2019). The use of Quipper School media supports fun and interesting learning process for students to learn. This is consistent with the 
research of several experts who state that the application of Quipper School in learning will increase student motivation on aspects of attention, relevance, and self-confidence. While the satisfaction aspects of learning tend to be the same when implementing Quipper School or classroom learning (face to face). This situation proves that the use of Quipper School media based on blended learning can improve students in learning which will ultimately improve learning outcomes (Irdianto \& Putra, 2016; Mukhadis, Putra, Nidhom, Dardiri, \& Suswanto, 2018; A. B. R. N. Putra, Mukhadis, Soraya, \& Dzakiya, 2019).

Students are more interested and can learn independently because Quipper School has provided links that have been recommended to broaden the understanding of the material that is ongoing, students can also directly answer questions that have been provided and can immediately find out the value obtained along with the correct answers and discussion (Mukhadis et al., 2018; A. B. N. R. Putra, Mukhadis, Poerwanto, Irdianto, \& Sembiring, 2019). In addition, during the workshop and coaching, the majority of participants answered that the use of e-learning, especially Quipper School, was easy and important for the learning process. On the other hand, using Edmodo and Quipper School together provides facilities for students to work independently, enabling students to improve the quality of learning and have more practical, interactive and interesting features.

\section{Conclusions}

Based on the results of research and discussion previously stated, the following research conclusions can be drawn. First, Quipper School has several advantages to help the learning process. These advantages include: (1) students can learn independently whenever and wherever they are without waiting for face-to-face learning in class; (2) fun and interesting learning for students through various features, display material, and videos; (3) students can practice as many questions as possible to deepen competence in the realm of knowledge; (4) students' lack of understanding can be directly addressed through the discussion feature between teacher and student and fellow students; and (5) the teacher can monitor the progress of student learning through student statistical features. Second, the Quipper School media produced are based on blended learning and can improve student learning outcomes. Learning is done by combining faceto-face learning with online learning, so students can learn wherever and whenever they are and can increase understanding related to learning material in the realm of knowledge.

\section{References}

1. Akhyar, Sajidan, Akhyar, M., \& Suryani, N. (2019). Development Frameworks Of The Indonesian Partnership 21st -Century Skills Standards For Prospective Science Teachers: A 
Delphi Study. Jurnal Pendidikan IPA Indonesia, 8(1), 89-100.

2. Bedir, H. (2019). Pre-service ELT teachers' beliefs and perceptions on 21st-century learning and innovation skills (4Cs). Journal Of Language And Linguistic Studies, 15(1), 231-246.

3. Broton, K. M. (2019). Rethinking the Cooling Out Hypothesis for the 21st Century: The Impact of Financial Aid on Students ' Educational Goals. Community College Review, 47(1), 79-104.

4. Burac, M. A. P., Fernandez, J. M., Cruz, M. M. A., \& Cruz, J. Dela. (2019). Assessing the impact of e-learning system of higher education institution ' $s$ instructors and students. In IOP Conf. Series: Materials Science and Engineering.

5. Chai, C. S., Koh, J. H. L., \& Teo, Y. H. (2019). Enhancing and Modeling Teachers' Design Beliefs and Efficacy of Technological Pedagogical Content Knowledge for 21st Century Quality Learning. Journal of Educational Computing Research, 57(2), 360-384.

6. Chan, E. Y. M. (2019). Blended Learning Dilemma: Teacher Education in the Confucian Heritage Culture. Australian Journal of Teacher Education, 44(1), 36-51.

7. Daniels, M., Sarte, E., \& Cruz, J. Dela. (2019). Students ' perception on e-learning : a basis for the development of e- learning framework in higher education institutions. IOP Conf. Series: Materials Science and Engineering, 482, 1-7.

8. Elsawy, A. M., \& Ahmed, O. S. (2019). E-Learning using the Blackboard system in Light of the Quality of Education and Cyber security. International Journal of Current Engineering and Technology, 9(1), 49-54.

9. Han, F., \& Ellis, R. A. (2019). Initial Development and Validation of the Perceptions of the Blended Learning Environment Questionnaire. Journal of Psychoeducational Assessment, $00(0), 1-14$.

10. Henritius, E., Löfström, E., \& Hannula, M. S. (2019). University students’ emotions in virtual learning: A review of empirical research in the 21st century. British Journal of Educational Technology, 50(1), 80-100.

11. Hu, J., Hu, J., Liu, H., Chen, Y., \& Qin, J. (2018). Strategic planning and the stratification of Chinese higher education institutions International Journal of Educational Development Strategic planning and the strati fi cation of Chinese higher education institutions. International Journal of Educational Development, (May).

12. Irdianto, W., \& Putra, A. B. N. R. (2016). The Influence of Education and Economic Background Towards The Training Participants ' Motivation and Study Result of UPT-PK Singosari Malang. In AIP Conference Proceeding (Vol. 1778, pp. 1-7).

13. Kembara, M. D., Rozak, R. W. A., \& Hadian, V. A. (2019). Research-based Lectures to 
Improve Students' 4C (Communication, Collaboration, Critical Thinking, and Creativity) Skills. In International Symposium on Social Sciences, Education, and Humanities (Vol. 306, pp. 22-26).

14. Khlaisang, J., \& Songkram, N. (2019). Designing a Virtual Learning Environment System for Teaching Twenty-First Century Skills to Higher Education Students in ASEAN. Technology, Knowledge and Learning, 24(1), 41-63.

15. Kim, S., Raza, M., \& Seidman, E. (2019). Improving 21st-century teaching skills : The key to effective 21st- century learners. Research in Comparative \& International Education, 14(1), $99-117$.

16. Kong, S. C. (2019). Partnership among Schools in E-Learning Implementation: Implications on Elements for Sustainable Development. International Forum of Educational Technology \& Society, 22(1), 28-43.

17. M Mustari, Hoya, A. L., Akmansyah, M., Diani, R., \& Asyhari, A. (2019). Development of E-Learning Based Blogs on Global Warming Subject Development of E-Learning Based Blogs on Global Warming Subject. In IOP Conf. Series: Journal of Physics: Conf. Series (pp. 1-10).

18. Mcguinness, C., \& Fulton, C. (2019). Digital Literacy In Higher Education: A Case Study Of Student Engagement With E-Tutorials Using Blended Learning. Journal of Information Technology Education: Innovations in Practice, 18, 1-28.

19. Melo, M. (2018). The 4C/ID-Model in Physics Education: Instructional Design of a Digital Learning Environment to Teach Electrical Circuits. International Journal of Instruction, 11(1), 103-122.

20. Montgomery, A. P., Mousavi, A., Carbonaro, M., Hayward, D. V, \& Dunn, W. (2019). Using learning analytics to explore self-regulated learning in flipped blended learning music teacher education. British Journal of Educational Technology, 50(1), 114-127.

21. Mukhadis, A., Putra, A. B. N. R., Nidhom, A. M., Dardiri, A., \& Suswanto, H. (2018). The Relevance of Vocational High School Program With Regional Potency Priority in Indonesia. Journal of Physics: Conference Series, 1028, 1-8.

22. Pandit, D., Joshi, M. P., Gupta, R. K., \& Sahay, A. (2017). Disruptive innovation through a dynamic capabilities lens: an exploration of the auto component sector in India 'Disruptive innovation through a dynamic capabilities lens: an exploration of the auto component sector in. Int. J. Indian Culture and Business Management, 14(1), 109-130.

23. Putra, A. B. N. R., Mukhadis, A., Poerwanto, E. E., Irdianto, W., \& Sembiring, A. I. (2019). LMS Technology by Using Makerspace Approach on Unique Experiments-Based through 
MOOCs in Improving the Professional Competence of Vocational Students Paper. In 3rd International Conference on Sustainable Information Engineering and Technology, SIET 2018 - Proceedings IEEE (pp. 312-316). IEEE.

24. Putra, A. B. R. N., Mukhadis, A., Soraya, D. U., \& Dzakiya, N. (2019). The Innovation of Hybrid Learning through Live 24-Hour Streaming Personal in the Learning Process in Higher Education of Vocational in the Era of Industrial Revolution 4 . 0. In 2nd International Conference on Vocational Education and Training (ICOVET 2018) The (Vol. 242, pp. 266270).

25. Ranieri, M., Raffaghelli, J., \& Pezzati, F. (2018). Building cases for faculty development in e-learning: a design-based approach. Open Journal per La Formazione in Rete, 18(1), 67-82.

26. Saggaf, M. S., Salam, R., Wirawan, H., \& Hasanuddin, U. (2018). The Influence of Teacher's Pedagogic Competence on Learning Motivation of Student of Office Administration Expertise Package. In 8th International Conference of Asian Association of Indigenous and Cultural Psychology (Vol. 127, pp. 111-114).

27. Schietroma, E. (2019). Innovative Stem Lessons, Clil And Ict In Multicultural Classes. Journal of E-Learning and Knowledge Society, 15(1), 183-193.

28. Simarmata, J., Djohar, A., Purba, J., \& Juanda, E. A. (2018). Design of a Blended Learning Environment Based on Merrill's srinciples Design of a Blended Learning Environment Based on Merrill 's Principles. In Journal of Physics: Conference Series (pp. 1-5).

29. Skorton, D. (2019). Branches from the same tree : The case for integration in higher education. PNAS Direct Submission, 116(6), 1865-1869.

30. Srinivasan, R., Al-omairi, A. S. K., Muppidathi, V., \& Al-balushi, A. M. I. (2019). Blended Learning method for Medium Power Transmission Line Performance Study. International Research Journal of Engineering and Technology, 6(3), 114-118.

31. Strekalova, Y. A., Karimipour, N., James, V., \& Treise, D. (2018). Assessing Risk Perceptions of E-Smoking Devices: a Cross-Sectional Consumer Survey. The Journal of Behavioral Health Services \& Research.

32. Yeop, M. A., Yaakob, M. F. M., Wong, K. T., Don, Y., \& Zain, F. M. (2019). Implementation of ICT Policy ( Blended Learning Approach ): Investigating factors of Behavioural Intention and Use Behaviour. International Journal of Instruction, 12(1), 767-782.

33. Zulkarnaen, R. H., Setiawan, W., Rusdiana, D., \& Muslim, M. (2019). Smart city design in learning science to grow 21 st century skills of elementary school student. In IOP Conf. Series: Journal of Physics: Conf. Series (pp. 1-7). 